\title{
Social and psychological aspects of venereal disease in Papua New Guinea
}

\author{
GAVIN HART \\ Taurama Medical Centre, Port Moresby
}

Traditional sexual mores vary greatly from one area to another, but promiscuity, and prostitution in particular, of the type encountered in Western Society, is rare in New Guinea culture (BurtonBradley, 1972). While in some traditional groups premarital sexual experience is common, disapproval of promiscuity of married women is virtually universal, although Malinowski (1932) has described how a Trobriand Chief married young women and prostituted them. Contact with Western civilization has modified these traditional restrictions, most noticeably in urban areas, and diverse new patterns of sexual behaviour have emerged.

Venereal disease was probably introduced to New Guinea, either directly or indirectly, by Europeans (Maddocks, 1967a). Whereas it is likely that early European sailors or explorers introduced gonorrhoea, the coloured followers of these Europeans were probably responsible for the introduction of Donovanosis. The Australian aborigines and inhabitants of some islands between Australia and New Guinea, themselves heavily infected with this latter disease, possibly transmitted it to their Papuan neighbours. It was noted that labourers returning from the Queensland canefields were infected (British New Guinea Report, 1900).

Following its introduction, the transmission of venereal infection was facilitated by ritual promiscuity associated with certain ceremonies and by the greater ease of communication introduced by European control. Some children, and possibly some adults, were probably infected with Donovanosis by direct body contact with their parents or relatives (Zigas, 1971).

Gonorrhoea, which is almost certainly the most common venereal infection, occurs throughout Papua New Guinea. In New Ireland depopulation by 27.1 per cent. between 1930 and 1951 has been attributed to this disease (Gunther, 1972). Donovanosis, while generally rarer than gonorrhoea, is very

Received for publication February 22, 1974

Present address: Venereal Diseases Branch, Center for Disease Control, Atlanta, Georgia 30333, U.S.A. common along the South coast of Papua where it is possibly as prevalent as in any other area of the world. It was common in the East of Papua, where the total V.D. incidence was 5.2 per cent. in 1905, and in West New Guinea up to 25 per cent. of some populations were infected in the 1920s (Maddocks, 1967a). A patrol through the Goilala area (100 miles NorthWest of Port Moresby) in 1946 detected 422 cases of Donovanosis and 362 cases of gonorrhoea among 8761 patients screened. In 1951 , in the same area, Zigas (1971) found that 4.9 per cent. of those over 15 years of age were infected.

The rarity of syphilis in New Guinea has been attributed to cross-immunity from yaws infection which was prevalent until 1958 when it was largely eradicated. Subsequently this immunity has decreased as evidenced by a fall in the incidence of positive TPI tests from $29 \cdot 3$ per cent. in $1964-5$ to $18 \cdot 1$ per cent. in 1968 (Garner and Hornabrook, 1970). In 1968, in this Highlands region, only 3.9 per cent. of children under the age of 15 years had positive serological tests; this was attributed to yaws as there was no clinical evidence of syphilis in those examined. More recently, syphilis has been detected, and it has been postulated that infection had been acquired at Lae, a northern seaport, and introduced along the Highlands Highway to a community with lessened immunity (Rhodes and Anderson, 1970).

Port Moresby, the first city of Papua New Guinea, is the largest urban area in the country, with a population of 51,000 indigenes $(31,500$ males and 19,500 females) and 15,000 non-indigenes (mostly European). Venereal disease in the Port Moresby area is treated at:

(i) The V.D. clinic, Taurama Hospital

This clinic treats almost all indigenous patients of the lower socioeconomic class, and referred patients from other medical facilities.

(ii) The army services

Several thousand service personnel, dependants, and civilian employees of the Army utilize these services. 


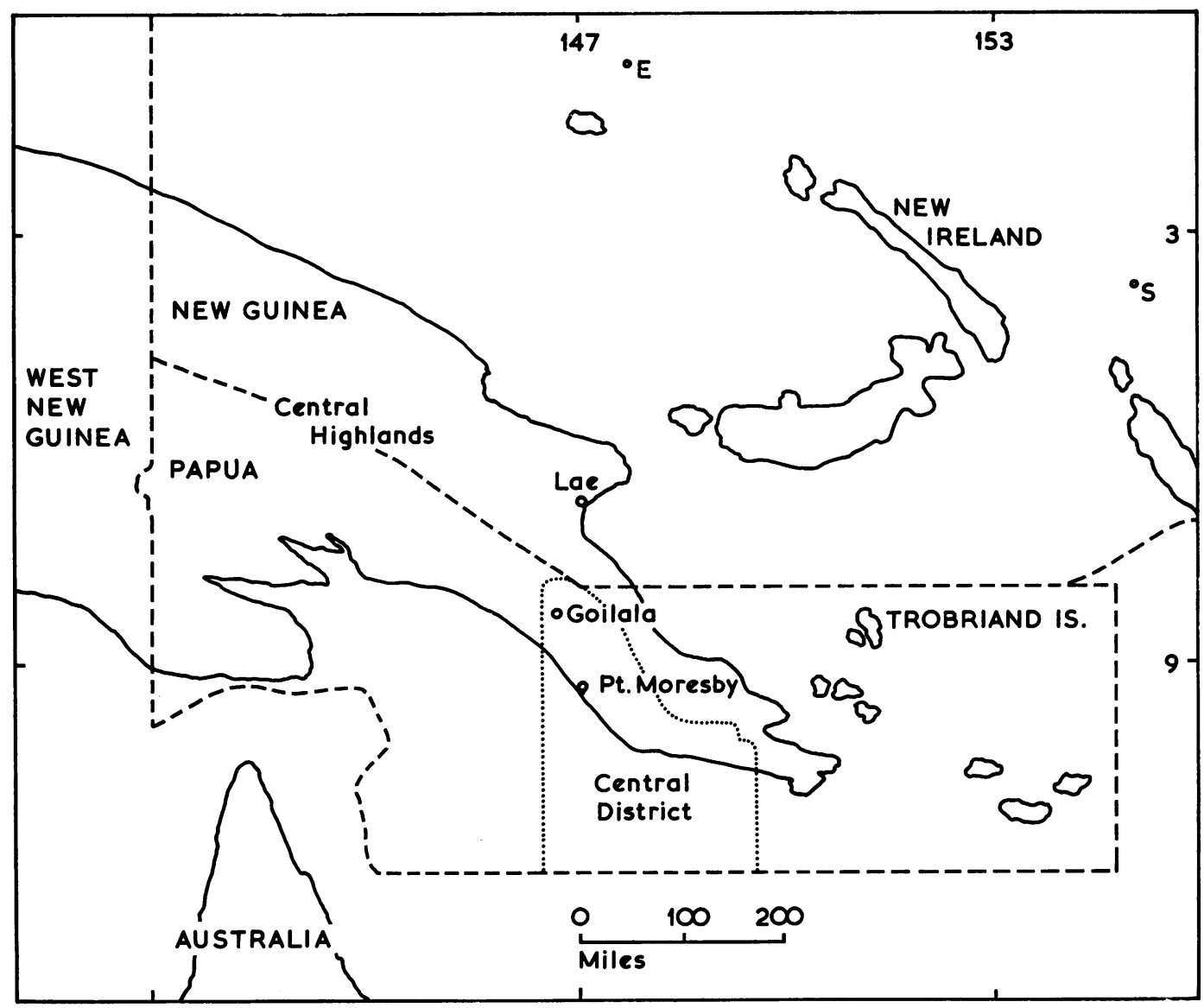

(iii) General practitioners

These private doctors treat most of the European population.

(iv) University medical services

(v) Other general and gynaecological clinics

This paper describes indigenous patients seen at the V.D. clinic and Army clinics.

\section{Clinical background}

There was little similarity between the civilian and Army patients. Although effective diagnostic aids were, in practice, limited at the civilian clinic, this was alleviated by use of Army services for cases of special interest.

The total incidence of venereal disease is unknown for both civilian and Army populations, though in the latter it probably approximates to 50/1,000/year. In $1972,1,534$ males (841 (55 per cent.) with gonorrhoea, 364 (23.5 per cent.) with Donovanosis, and 329 (21.5 per cent.) with other diseases) and 316 females (159 with gonorrhoea and 157 with other diseases) were seen at the civilian clinic. Among soldiers, gonorrhoea was the commonest infection, but Donovanosis was rare, although it was common among civilian employees of the Army. Clinical chancroid and lymphogranuloma venereum were occasionally seen at both clinics. Syphilis was rare among civilian males although a few cases, mostly secondary, were seen among soldiers. Non-gonococcal urethritis, while common in Europeans in Port Moresby, was much rarer in indigenous patients. Among prostitutes induced to attend the clinic, gonorrhoea was common, but several cases of syphilis, both primary and secondary, were also seen.

Most of the soldiers sought treatment promptly, but the civilians commonly tolerated their lesions weeks or months before attending the clinic. Whereas full surveillance was conducted on all Army patients, 
asymptomatic civilians rarely returned. Approximately 75 per cent. of Donovanosis patients, however, continued to attend the clinic weekly while their lesions were active.

\section{Sociological studies}

In order to quantitate aspects of the sociological environment, a simple proforma was completed on venereal disease patients at both the civilian and Army clinics in 1972. The Army study was restricted to soldiers of sergeant's rank and below, and fifty consecutive venereal disease patients were compared with 250 consecutive patients without venereal disease treated in the same period (Table I). Significant differences were detected by $\chi^{2}$ calculations.

TABLE I Comparison of military venereal disease patients with a control series from army clinics in Port Moresby

\begin{tabular}{|c|c|c|c|c|c|c|}
\hline \multirow[b]{2}{*}{ Parameter } & & \multicolumn{2}{|c|}{$\begin{array}{l}\text { V.D. } \\
\text { patients }\end{array}$} & \multicolumn{2}{|c|}{ Controls } & \multirow{3}{*}{$P$} \\
\hline & & No. & $\mathrm{Per}$ & No. & $\mathrm{Per}$ & \\
\hline Rank & $\begin{array}{l}\text { Private } \\
\text { NCO }\end{array}$ & $\begin{array}{r}42 \\
8\end{array}$ & $\begin{array}{l}84 \\
16\end{array}$ & $\begin{array}{r}184 \\
66\end{array}$ & $\begin{array}{l}74 \\
26\end{array}$ & \\
\hline Age (yrs) & $\begin{array}{l}\text { Under } 21 \\
21-25 \\
26-30 \\
\text { Over } 30\end{array}$ & $\begin{array}{r}12 \\
33 \\
4 \\
1\end{array}$ & $\begin{array}{r}24 \\
66 \\
8 \\
2\end{array}$ & $\begin{array}{r}78 \\
130 \\
32 \\
10\end{array}$ & $\begin{array}{r}31 \\
52 \\
13 \\
4\end{array}$ & $>0.10$ \\
\hline $\begin{array}{l}\text { Length of } \\
\text { service (yrs) }\end{array}$ & $\begin{array}{l}\text { Under } 6 \\
6-10 \\
\text { Over } 10\end{array}$ & $\begin{array}{r}31 \\
15 \\
4\end{array}$ & $\begin{array}{r}62 \\
30 \\
8\end{array}$ & $\begin{array}{r}161 \\
70 \\
19\end{array}$ & $\begin{array}{r}64 \\
28 \\
8\end{array}$ & $>0.90$ \\
\hline Religion & $\begin{array}{l}\text { Roman catholic } \\
\text { Protestant } \\
\text { Other }\end{array}$ & $\begin{array}{r}19 \\
30 \\
1\end{array}$ & $\begin{array}{r}38 \\
60 \\
2\end{array}$ & $\begin{array}{r}97 \\
122 \\
31\end{array}$ & $\begin{array}{l}39 \\
49 \\
12\end{array}$ & $<0.10$ \\
\hline $\begin{array}{l}\text { Marital } \\
\text { status }\end{array}$ & $\begin{array}{l}\text { Married } \\
\text { Single }\end{array}$ & $\begin{array}{l}10 \\
40\end{array}$ & $\begin{array}{l}20 \\
80\end{array}$ & $\begin{array}{r}68 \\
182\end{array}$ & $\begin{array}{l}27 \\
73\end{array}$ & $>0.20$ \\
\hline $\begin{array}{l}\text { Length of } \\
\text { education } \\
\text { (yrs) }\end{array}$ & $\begin{array}{l}\text { Under } 6 \\
6 \\
\text { Over } 6\end{array}$ & $\begin{array}{r}7 \\
24 \\
19\end{array}$ & $\begin{array}{l}14 \\
48 \\
38\end{array}$ & $\begin{array}{r}38 \\
142 \\
70\end{array}$ & $\begin{array}{l}15 \\
57 \\
28\end{array}$ & $>0.30$ \\
\hline $\begin{array}{l}\text { Army } \\
\text { charges }\end{array}$ & $\begin{array}{l}\text { Nil } \\
1 \text { or more }\end{array}$ & $\begin{array}{l}21 \\
29\end{array}$ & $\begin{array}{l}42 \\
58\end{array}$ & $\begin{array}{r}157 \\
93\end{array}$ & $\begin{array}{l}63 \\
37\end{array}$ & $<0.01$ \\
\hline District & $\begin{array}{l}\text { Highlands } \\
\text { Islands } \\
\text { Coastal }\end{array}$ & $\begin{array}{r}20 \\
21 \\
9\end{array}$ & $\begin{array}{l}40 \\
42 \\
18\end{array}$ & $\begin{array}{r}74 \\
52 \\
124\end{array}$ & $\begin{array}{l}30 \\
21 \\
49\end{array}$ & $<0.001$ \\
\hline
\end{tabular}

Table II shows the social background of 200 consecutive new male patients seen at the civilian clinic. In addition, thirty prostitutes attending this clinic were interviewed.

\section{Observations}

(1) Among Army patients, 31 (62 per cent.) had gonorrhoea and nineteen (38 per cent.) had other venereal diseases. Nineteen ( 38 per cent.) had been drinking and another twelve ( 24 per cent.) were drunk
TABLE II Social parameters of 200 male civilians with venereal disease

\begin{tabular}{|c|c|c|c|c|c|}
\hline \multicolumn{2}{|l|}{ Parameter } & \multirow{2}{*}{$\begin{array}{r}\text { No. } \\
42 \\
158\end{array}$} & \multicolumn{2}{|c|}{ Parameter } & No. \\
\hline $\begin{array}{l}\text { Marital } \\
\text { status }\end{array}$ & $\begin{array}{l}\text { Married } \\
\text { Single }\end{array}$ & & District & $\begin{array}{l}\text { Highlands } \\
\text { Islands }\end{array}$ & 127 \\
\hline \multirow[t]{2}{*}{ Age (yrs) } & Under 21 & 67 & & Other Coastal & 51 \\
\hline & $\begin{array}{l}21-25 \\
\text { Over } 30\end{array}$ & $\begin{array}{l}3 \\
45 \\
35\end{array}$ & \multirow[t]{2}{*}{$\mathrm{Fee}^{\mathrm{a}}$} & \multirow{2}{*}{$\begin{array}{l}\text { Free } \\
\text { Under } 1 \text { dollar } \\
1 \text { dollar } \\
2 \text { dollars } \\
\text { Over } 2 \text { dollars } \\
\text { Goods }\end{array}$} & \\
\hline $\begin{array}{l}\text { Length of } \\
\text { education } \\
\text { (yrs) }\end{array}$ & $\begin{array}{l}\text { Nil } \\
1-3 \\
4-6\end{array}$ & $\begin{array}{r}\overline{102} \\
42 \\
31\end{array}$ & & & 5 \\
\hline & & & \multirow{2}{*}{ Location $^{\mathrm{a}}$} & House & \\
\hline $\begin{array}{l}\text { Previous } \\
\text { infection }\end{array}$ & $\begin{array}{l}\text { Yes } \\
\text { No }\end{array}$ & $\begin{array}{r}29 \\
171\end{array}$ & & $\begin{array}{l}\text { Bush } \\
\text { Other }\end{array}$ & 22 \\
\hline Contact & $\begin{array}{l}\text { Denied } \\
\text { Prostitute } \\
\text { Friend }\end{array}$ & $\begin{array}{r}5 \\
182 \\
13\end{array}$ & & & \\
\hline $\begin{array}{l}\text { Type of } \\
\text { infection }\end{array}$ & $\begin{array}{l}\text { Gonorrhoea } \\
\text { Penile sore }\end{array}$ & $\begin{array}{r}\overline{145} \\
55\end{array}$ & & & \\
\hline
\end{tabular}

aFive patients with gonorrhoea denied sexual contact.

at the time of sexual contact, which was with a prostitute in 38 (76 per cent.) cases. Only 6 per cent. had had previous venereal infection.

Although the V.D. and control series did not differ significantly regarding marital status, the majority of married controls were living with their wives, whereas of the ten married V.D. patients, nine were separated from their wives because of lack of accommodation and the tenth was not currently having intercourse with his wife because of her advanced pregnancy.

(2) Among the civilians, five patients (2.5 per cent.) with gonorrhoea denied any sexual contact. The distinction between prostitute and friend as contacts for the remainder was not sharply defined, as two of the thirteen who named a friend paid for their sex, whereas 42 of the 182 who named prostitutes did not pay for intercourse. Payment in goods varied from two cigarettes to bottles of beer and assorted foods.

Intercourse occurred mostly out-of-doors (102; 51 per cent.), and in almost half of these cases (45) during daylight hours. Other locations included houses, the beach, the roadside, a boat, and the back of a truck.

Of the married patients, 28 had left their wives in their village, and seven of the remaining fourteen had acquired venereal disease from their wives who were prostitutes.

(3) Of the thirty prostitutes interviewed, fifteen (50 per cent.) were under 21 years old and fifteen were aged between 21 and 30 years. There were nineteen from highland districts and eleven from coastal districts. Of the highlanders, sixteen were 
married and none had attended school. Of the coastal girls, five were married and all had attended school. The highest fee was 10 dollars, routinely charged by a coastal girl, and the total income from prostitution varied from 20 dollars a day to 20 dollars a week (the standard male labourer's weekly salary is 9 dollars).

\section{Discussion}

The type of sexual outlet among the indigenous population varies markedly with socioeconomic factors. Among married Papuans in Port Moresby, promiscuity is rare. In the better educated groups, promiscuity for pleasure and steady partnerships are the major premarital outlets. Although venereal disease is not uncommon in this latter group, extramarital pregnancy is probably the most significant sequel of such premarital intercourse. For single labourers and married immigrants separated from their wives, recourse to prostitutes and, to a lesser extent, homosexual behaviour are more common outlets and venereal disease is a prominent sequel.

The continuing immigration of unaccompanied male labourers from rural areas in the past 15 years is reflected in the excess male indigenous population of Port Moresby (62 per cent. greater than the female population), a situation which is conducive to the development of prostitution. In its earliest stages prostitution was established in domestic servants quarters where a girl was visited by indigenous (and occasionally European) clients. Later, with increasing demand, private houses were used for prostitution (mostly Papuan and mixed race prostitutes) and certain suburbs of the developing town were recognized as areas for this trade. The increased incidence of Donovanosis in 1964-65 has been attributed to this proliferation in one area (Maddocks, 1967a).

After the legalization of indigenous drinking in 1962, taverns and drinking places became common meeting places for prostitutes and clients, but the highly organized bar-brothels characteristic of many Asian countries have not yet developed.

As the population has continued to increase, some women have accompanied the male immigrants, squatter settlements have developed, and a further form of prostitution has evolved. Husbands and brothers of highland women, by prostituting their wives and sisters, are able to obtain a much greater income than they could by any legal means. These women, with no formal education, mostly unable to speak even pidgin English, and traditionally of markedly inferior social status to their husbands and brothers who act as pimps, occupy an almost identical social position to that of the 'dress house' prostitutes of 19th century England-the most exploited and helpless of all prostitutes.

Throughout the suburbs of Port Moresby there are many women who are readily solicited for sexual purposes. These women, who provide a large proportion of prostitute contacts, could not be classed as conventional streetwalkers, as in most cases the initiative for any contract rests with the male client, and at the time of contact the women are usually engaged in some other activity rather than loitering explicitly for sexual purposes.

The soldiers and civilians studied represent two widely divergent socioeconomic groups (e.g. 86 per cent. of the soldiers had completed primary education whereas 51 per cent. of the civilians had not attended school) and this contrast is reflected in the types of partner chosen by each group.

The soldiers mostly made contact with prostitutes at night or at the weekend when they visited an eating or drinking house in or near Port Moresby. One inn several miles from Port Moresby was a particularly popular weekend drinking haunt of soldiers and many contacts were made with the prostitutes who were always in attendance. Thus promiscuity represented part of a leisure activity (62 per cent. had been drinking at the time of contact) and the partners were relatively sophisticated prostitutes who were present explicitly for sexual purposes.

Among the civilians studied, intercourse was often arranged with a pimp who was paid a standard fee (usually 2 dollars), after which the client had intercourse, out-of-doors, with the unsophisticated dependant. Not infrequently, however, intercourse occurred after a chance daylight encounter with an unaccompanied woman (most commonly a Papuan), who, because of the impromptu nature of the contract, was paid a nominal fee or with any goods that were at hand. Such encounters occurred while the partners were at the beach, bathing in a stream, in a truck or boat, or, most commonly, walking through the suburban bush.

No soldiers and 6.5 per cent. of civilians infected with V.D. were from the Central District. Most were either single or had left their wives at the village and most of them contracted their infection from prostitutes. For soldiers, venereal infection was associated with military crime (58 per cent. of patients compared with 37 per cent. of controls having been charged), but otherwise there was little difference between patients and controls. This relationship of venereal infection to migration of a labour force, together with the absence of any distinct high risk group, has also been noted in at least one other developing country (Verhagen and Gemert, 1972). Furthermore, only 6 per cent. of soldiers and 15 per cent. of civilians had been previously infected. This 
contrasts with the situation in western society where a small proportion of the population often makes a large contribution to the venereal disease problem (Brown, 1961; Willcox, 1962; Lomholt and Berg, 1966; Glass, 1967).

The common and diverse emotional sequelae following exposure to venereal infection among Europeans has been described (Hart, 1973), whereas Mbanefo (1968) considers that Nigerians view gonorrhoea with a 'fear of almost phobic intensity'. The attitudes of New Guineans to venereal infection are quite different and have public health implications as well as personal consequences. These attitudes vary fairly consistently with the degree of formal education.

(i) Among the less sophisticated, with no formal education, there tends to be a complacency, bordering on disregard, for some forms of venereal disease. Pain or gross distortion of the genitalia motivate attendance for treatment, but other symptoms tend to be tolerated. Thus patients with gonorrhoea probably attend because of associated dysuria. The absence of nongonococcal urethritis in patients attending for treatment must be considered against this background. The milder symptoms and the high spontaneous remission rate probably cause it to be disregarded. This hypothesis is supported by a study on Reiter's disease in Port Moresby in which non-gonococcal urethritis was frequently disclosed on examination, although the patients had not previously complained of the condition (Maddocks, 1967b).

Donovanosis, which mostly produces only moderately painful lesions, is frequently selftreated for weeks or months before medical care is sought, at which stage widespread permanent destruction of genital tissue has often occurred. As the chancre of syphilis is usually painless and heals spontaneously in a few weeks it is likely that patients with this condition would not seek medical treatment. This would explain why syphilis, although present in the community as evidenced from the examination of prostitutes and soldiers, is rarely seen at the civilian clinic. At least one section of the community may be accumulating an increasing proportion of latent syphilitics and the return of these infected labourers to their home district could be responsible for an increasing incidence of syphilis in many areas of Papua New Guinea. The task of detecting those with latent infection in a primitive community, where up to 20 or 30 per cent. of the population may be serologically positive due to past yaws infection, is a formidable one. Venereo-neurosis (Hart, 1973) was not seen in this uneducated group but is common in other patients.

(ii) Refusal to accept cure of venereal infection was a common feature in military patients, particularly those with primary or minimal secondary education. These patients were depressed and unresponsive to reassurance. The results of other forms of therapy (parenteral antibiotic, placebo, antidepressants) were unimpressive.

(iii) Among patients with secondary or further education, both civilian and military, hypochondriasis is the most common manifestation of venereo-neurosis, with persistent undue concern over urethral sensations or secretions. Reassurance alone rarely convinced these patients, and this was usually reinforced with a course of a broad-spectrum antibiotic. However, the majority became chronic attenders.

\section{Summary}

Correlations of social factors with venereal disease in Port Moresby, the largest town in Papua New Guinea, were sought by interviewing fifty military V.D. patients and 250 military controls, two hundred consecutive civilian male V.D. patients, and thirty prostitutes.

The military patients did not differ significantly from the controls with regard to rank, age, length of service, religion, or education. However, 58 per cent. of V.D. patients compared with 37 per cent. of controls had been convicted of a military crime. Virtually all military and civilian patients were from other parts of Papua New Guinea and were single or separated from their wives. Only 6 per cent. of military and 15 per cent. of civilian patients had had previous venereal infection.

76 per cent. of Army patients and 91 per cent. of civilians acquired their infections from prostitutes, but the type of prostitute contact differed markedly for the two groups. Soldiers mainly contacted a relatively sophisticated prostitute at a place of entertainment during their leisure hours at night or on weekends. 38 per cent. had been drinking and another 24 per cent. were drunk at the time of sexual contact.

By contrast, the civilians acquired infection from unsophisticated women who were prostituted by their husbands or brothers, or following chance encounters in suburban areas. In 51 per cent. of cases intercourse occurred out-of-doors and for 23 per cent. during the daylight hours. Prostitutes encountered on the streets provided a significant sexual outlet for both soldiers and civilians. 
The attitudes of Papua New Guineans to venereal disease are closely related to degree of education and have public health implications as well as personal consequences. Venereo-neurosis is rare in the uneducated in whom there is complacency, bordering on disregard, towards genital infections. This probably accounts for the rarity of non-gonococcal urethritis and syphilis in patients attending this clinic, although the diseases occur in other sections of the community. Venereo-neurosis is mainly manifest as depressive illness in those with moderate education and hypochondriasis in those with higher education. Both groups are reluctant to accept reassurance and the results of other forms of therapy have been unimpressive.

Mr. Lister Tom assisted in the collection of data from the civilian clinic and Professor I. Maddocks and Dr. J. Collins provided constructive criticism of the manuscript.

\section{References}

British New Guinea Report (1900) Her Majesty's Special Commission Report 1886-1899 for the Protected Territory.' Appendix C. H.M.S.O., London

Brown, W. J. (1961) Bull. WHO, 24, 386

BURTON-BRADLEY, B. G. (1972) 'Prostitution ' in 'Encyclopedia of Papua New Guinea', p. 977. Melbourne University Press, Melbourne

GARNER, M. F., and HorNabrook, R. W. (1970) Brit. F. vener. Dis., 46, 13

GLass, L. H. (1967) Ibid., 43, 128

GUNTHER, J. T. (1972) 'History of Medical Services' in 'Encyclopedia of Papua New Guinea,' p. 754. Melbourne University Press, Melbourne

HART, G. (1973) Soc. Sci. Med., 7, 455

LOMHOLT, G., and BeRG, O. (1966) Brit. F. vener. Dis., 42, 1

Maddocks, I. (1967a) Papua New Guinea med. F., 10, 49 — (1967b) Brit. F. vener. Dis., 43, 280

Malinowski, B. (1932) 'The Sexual Life of Savages'. Routledge and Kegan Paul, London

Mbankfo, S. E. (1968) f. roy. Coll. gen. Practit., 15, 272

RHodes, F. A., and ANDerson, S. E. J. (1970) Papua New Guinea med. F., 13, 49

Verhagen, A. R., and Gemert, W. (1972) Brit. F. vener. Dis., 48, 277

Willcox, R. R. (1962) Brit. f. prev. soc. Med., 16, 113

Zigas, V. (1971) Papua New Guinea med. F., 14, 148
Aspects sociaux et psychologiques des infections vénériennes dans la Nouvelle Guinée anglaise

SOMMAIRE

On rechercha les rapports pouvant exister entre les facteurs sociaux et les maladies vénériennes à Port Moresby, la ville la plus importante de la Nouvelle Guinée anglaise, en interrogeant 50 vénériens militaires, 250 militaires non vénériens, 200 vénériens mâles consécutifs de la population civile et 30 prostituées.

Les vénériens militaires ne sont pas significativement différents des militaires non véneriens en ce qui concerne le grade, l'âge, la durée du service, la religion ou le niveau d'éducation. Cependant, 50 pour cent des malades véneriens avaient été reconnus coupables d'un manquement à la discipline, contre 37 pour cent pour les témoins. En pratique, tous les militaires et les malades civils étaient originaires d'autres régions de la Nouvelle Guinée anglaise; ils étaient célibataires ou séparés de leurs femmes. Six pour cent seulement des militaires et 15 pour cent des malades civils avaient eu une infection vénérienne antérieure.

Soixante-seize pour cent des malades de l'armée et 91 pour cent des civils s'étaient infectés avec des prostituées, mais le type des contacts prostitutionnels étaient très différents pour les deux groupes. Les soldats ont des contacts principalement avec des prostituées relativement évoluées, dans un lieu de plaisir, pendant leurs heures de loisir, le soir ou en fin de semaine. Trente huit pour cent avaient absorbé des boissons et 24 pour cent supplémentaires étaient ivres au moment du contact sexuel.

$\mathrm{Au}$ contraire, les civils se contaminent auprès de femmes non évoluées que leur mari ou frères poussent à la prostitution ou auprès de femmes rencontrées par hasard dans les faubourgs. Dans 51 pour cent des cas, le rapport avait eu lieu au dehors et, pour 23 pour cent, pendant la journée. Les prostituées rencontrées dans les rues offraient des occasions sexuellement significatives d'infection à la fois pour les soldats et pour les civils.

Les attitudes des Papous vis-à-vis des maladies vénériennes sont en relation directe avec le degré d'éducation et ont des impliquations tant du point de vue de la santé publique que vis-à-vis des conséquences personnelles La névrose vénérienne est rare chez les sujets non éduqués où l'on rencontre une insouciance, qui frise l'indifférence, touchant les infections génitales. Ceci intervient probablement pour expliquer la rareté des urétrites non gonococciques et de la syphilis chez les consultants de la clinique considérée, quoique ces maladies existent dans d'autres groupes de la communauté. La névrose vénérienne se manifeste principalement par une dépression chez ceux qui ont une éducation modérée et par de l'hypocondrie chez ceux d'un niveau plus élevé d'éducation. Les deux groupes acceptent difficilement les paroles rassurantes et le résultat des autres formes de traitement a été peu marqué. 